$12-2012$

\title{
'In a Settled Country, Everyone Must Eat': Four Questions About Transnational Private Regulation, Migration, and Migrant Work
}

Amar Bhatia

Osgoode Hall Law School of York University, abhatia@osgoode.yorku.ca

Source Publication:

German Law Journal

Follow this and additional works at: https://digitalcommons.osgoode.yorku.ca/scholarly_works

Part of the Indian and Aboriginal Law Commons, Labor and Employment Law Commons, and the Transnational Law Commons

(c) (1) $(9)$

This work is licensed under a Creative Commons Attribution-Noncommercial-No Derivative Works 4.0 License.

\section{Recommended Citation}

Bhatia, A. "'In a Settled Country, Everyone Must Eat': Four Questions About Transnational Private Regulation, Migration, and Migrant Work." German Law Journal, vol. 13, no. 12, 2012, pp. 1282-1295.

This Article is brought to you for free and open access by the Faculty Scholarship at Osgoode Digital Commons. It has been accepted for inclusion in Articles \& Book Chapters by an authorized administrator of Osgoode Digital Commons. 


\title{
Articles
}

\section{'In a Settled Country, Everyone Must Eat': Four Questions About Transnational Private Regulation, Migration, and Migrant Work}

\author{
By Amar Bhatia*
}

\section{A. Is Migration Always Transnational?}

First, I would like to acknowledge where this paper was presented and where the work of revising it into an article took place. I would like to acknowledge the territory, which is not just Toronto, Ontario, Canada, but also Tkaronto, a Mohawk or Kaniekehaka word (as are Ontario and Canada). This word is from one of the languages of the Six Nations that comprise the Haudenosaunee Confederacy (People of the Longhouse), perhaps better known in this symposium by the French colonial name of Iroquois. Toronto and its surrounding territory are traditionally of the Huron-Wendat people, the Seneca Nation of the Haudenosaunee, and with title most recently lying with the Mississaugas of New Credit (Anishinabe). ${ }^{1}$ I would like to acknowledge the territory and thank these hosts, as well as the conference organizers for their generous invitation to participate in these discussions on transnational private regulation (TPR).

This introduction speaks to one of the questions raised by transnational private regulation: is migration always transnational?

One quick answer to this question might be 'no'. If migration is concerned with the international movement of people, then what has been called the approach of methodological nationalism would force out the 'trans-' and always substitute the international. Since methodological nationalism is an approach characterized by an overdue emphasis on states and their external borders as the sole arbiters for what registers as movement, then this answer would not surprise anyone. ${ }^{2}$ However, if we do

Email: amar.bhatia@utoronto.ca. I would like to acknowledge the support of the editorial board of the German Law Journal, in seeing this piece through to publication.

${ }^{1}$ See for example, Victoria Freeman, "Toronto Has No History!" Indigeneity, Settler Colonialism, and Historical Memory in Canada's Largest City, 38(2) URBAN HISTORY REV. 21-22 (2010).

${ }^{2}$ On methodological nationalism, see Nina Glick Schiller, Beyond the Nation-State and its Units of Analysis: Towards a New Research Agenda for Migration Studies, in CONCEPTS AND MEthOdS IN MigRation ResearCH: CONFERENCE READER 39, 59-65 (Karin Schittenhelm ed., 2007), available online at: http://www.cultural-capital.net (last accessed: 18 November 2012). On transculturalism and the desire for fostering global labor market membership, including discussion of Schiller, methodological nationalism and Jennifer Gordon's proposals for transnational labor citizenship, see Leah Vosko, Out of the Shadows? The Non-Binding Multilateral Framework on 
not take a monopolistic approach to borders, where states are all that matters, then we must move beyond a 'Westphalian' approach to migration that sees only the interests and concerns of supposedly formally equal, sovereign states.

And this movement beyond includes moving beyond the important but not necessarily transformative changes that have taken place in the post-Westphalian system generally, or with respect to migration in particular. For example, our analysis must include the postWorld War II evolution of human rights that has co-evolved with state sovereignty and been tempered by capitalist and post-industrial revolutions and the mutations of ever more flexible forms of citizenship or denizenship. ${ }^{3}$ However, when answering the question of whether migration is always transnational in the affirmative, part of what I mean encompasses taking an urban, regional, and territorial approach to migration and the movement of people and peoples ${ }^{4}$.

In the context of Toronto/Tkaronto, Ontario, Canada, it is only being accurate to note that most recent migration has taken place not just 'to Canada' writ large, but to three major cities within Canada (the 'MTV' complex of Montreal, Toronto, Vancouver), to different provinces and regions (e.g. Ontario), and from some industries to others (e.g. fishing in the Maritimes, manufacturing in central Canada, to extractive industries in western Canada). Importantly, these different circulations of people within and outside Canada all take place across historical and contemporary territories and confederacies of Indigenous peoples and nations that persist despite the ongoing 'postage-stamp sized' reservation system in Canada. Equally importantly, Indigenous peoples are members of these migrations as well, forced, seasonal, and otherwise. Further, the regulation of migration includes international law, federal law, provincial law, municipal law, the common law, labor and employment laws, family law, and other laws and policies. ${ }^{5}$ The federal selection of permanent immigrants has been fragmented into a predominantly two-step approach to

Migration (2006) and Prospects for Using International Labor Regulation to Forge Global Labor Market Membership, in THE IDEA OF LABOR LAW 383 (Guy Davidov and Brian Langille eds., 2011).

${ }^{3}$ See for example, SAmuel Moyn, The Last Utopia: Human Rights in History (2010); Adolf Berle, The $20^{\text {Th }}$ Century CAPITALIST REVolution (1954); Barry Bluestone \& Bennett Harrison, The Deindustralization of America: Plant Closings, Community Abandonment, and the Dismantling of Basic Industies (1982); AIHWA ONG, NeOLIBERALISM AS

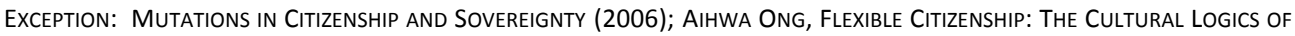
Transnationality (1999); Guy Standing, The Precariat: The NeW Dangerous Class (2011).

${ }^{4}$ See e.g. Rachel Buff, Immigration and the Political EConomy of Home: West Indian Brooklyn and American Indian MINNEAPOLIS ,1945-1992 (2001).

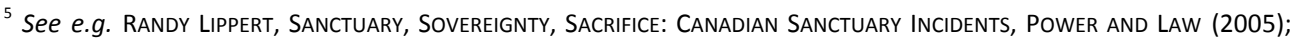
Sean Rehaag, Bordering on Legality: Canadian Church Sanctuary and the Rule of Law, 26 (1) RefUGE 43 (2009); Carolina Berinstein, Peter Nyers, Cynthia Wright \& Sima Zeheri, Access Not Fear: Non-Status Immigrants and City Services. REPORT PREPARED FOR THE 'DON'T ASK, DON'T TELL' CAMPAIGN TORONTO (2006); Erika Khandor, Jean McDonald, Peter Nyers \& Cynthia Wright, The Regularization of Non-Status Immigrants in Canada, 1960-2004: Past Policies, Current Perspectives, Active Campaigns. RePORT PREPARED FOR THE STATUS CAMPAIGN (2004). 
immigration. As well, much concern has been expressed about the shift in emphasis, priority of processing, and numbers from (a) high-skill immigrants and their families with permanent status on arrival selected by a national public governmental body and supported by settlement programs ${ }^{6}$ to (b) the expanded use of temporary, 'lower skill' and deskilled (also racialized and feminized) migrants being selected and vulnerable to private employers, corporations, universities and provinces without supports for settlement or viable pathways to permanent residence. ${ }^{7}$ Part of the motivation behind this expansion of the Temporary Foreign Worker Program (TFWP) stems from industry demands for garment and meat plant workers in Manitoba and, later, for semi-skilled trades and low-skilled service workers in the Alberta extractive industries seeking to expand in service of American and Chinese energy markets. The extraction and transmission of these resources in and across Western Canada also take place on the traditional territories of numerous Indigenous nations and are fraught with controversy. ${ }^{8}$

So, yes, migration is always already transnational, at least in a settler colonial state such as Canada. Although it is unwise to make blanket statements, it should also be clear that this answer can be extended to most of the world, since very few places have been left untouched by colonialism. As noted by Vine Deloria, Jr. in the 1974 foreword to The Fourth World: An Indian Reality, there is "presently no place on earth that a people can live without either asserting their own political independence against the European nations or attaching themselves to a European nation, (or nation deriving its government from that

\footnotetext{
${ }^{6}$ See Yessy Byl, Temporary Foreign Workers - Alberta's disposable workforce: The Six-Month Report of the AFL's Temporary Foreign Worker Advocate, ALBERTA FEDERATION OF LABOR (AFL, 2007); Yessy Byl, Entrenching Exploitation: The Second Report of the Alberta Federation of Labor Temporary Foreign Worker Advocate (AFL, 2009); David Tilson MP, Chair, Temporary Foreign Workers and Non-status Workers, REPORT OF THE STANDING COMMITTEE ON CitizenshiP AND IMmigRation, $40^{\text {th }}$ Parliament, $2^{\text {nd }}$ Session (2009); Naomi Alboim, Adjusting the Balance: Fixing Canada's Economic Immigration Policies, MAYTREe INSTITUTE (2009); Delphine Nakache \& Paula Kinoshita, The Canadian Temporary Foreign Worker Program: Do Short-Term Economic Needs Prevail Over Human Rights Concerns? Study No. 5 Institute for Research and Public Policy (2010), available online at: http://ssrn.com/abstract=1617255 (last accessed: 18 November 2012). More recently, see: Fay Faraday, Made in Canada: How the Law Constructs Migrant Workers' Insecurity (Metcalf Foundation, 2012), available online at: http://metcalffoundation.com/publications-resources/view/made-in-canada/ (last accessed: 4 December 2012).

${ }^{7}$ Id.

${ }^{8}$ See e.g. National Energy Board, Enbridge Northern Gateway Project Joint Review Panel by National Energy Board and Canadian Environmental Assessment Agency, available online at: http://gatewaypanel.reviewexamen.gc.ca/clf-nsi/index.html (last accessed: 18 November 2012); Robert Drinkwater, Groups ask Northern Gateway pipeline hearings about possibility of Chinese investment, WINDSOR STAR, Sep. 9, 2012, available online at: http://www.windsorstar.com/business/resources/Groups+pipeline+hearings+about+possibility+Chinese/7213255 Lstory.html (last accessed: 18 November 2012). For incisive reports on the Joint Review and Indigenous resistance to it, see Tyler McCreary, Enbridge issued final notice of trespass by Wet'suwet'en hereditary chiefs, Northern Notes, RABBLE.CA Aug. 5, 2010, available online: http://rabble.ca/blogs/bloggers/tylermccreary/2010/08/enbridge-issued-final-notice-trespass-wetsuwetenhereditary-ch-0 (last accessed: 18 November 2012). For the full column listing, see Tyler McCreary, Northern Notes, available online at: http://rabble.ca/category/bios/tyler-mccreary (last accessed: 18 November 2012).
} 
tradition)". ${ }^{9}$ Where the work of decolonization remains unfinished, the import and regulation of migration cannot be said to register at the international (inter-state) level alone.

\section{B. Is Migration Always Private?}

In unfolding the story of transnational private regulation, or transnational governance, or transnational regulatory governance, or private transnational governance regimes (as variously put by different presenters), the issue of the public-private divide was an elusive and 'itchy' one at the conference. ${ }^{10}$ Noting that his presentation would not address the terms transnational or private, especially because he found debate on the latter akin to guessing the number of angels on the head of a needle, ${ }^{11}$ Colin Scott focused his talk on regulation and the move from classical state regulation to market and community-based regulation. In this and related work, Peer Zumbansen has explored the distinction between public and private even while acknowledging, as we all must, its abiding prescriptive and descriptive force. ${ }^{12}$ And obviously the porous, mutually constituting divide is not a new issue. While Scott chose not to talk about 'transnational' or 'private' that day, his presentation plotted out a moving taxonomy of regulation, from:

1) Classical regulation (government agency B regulates firm A by rules, monitoring, enforcement, legislation);

2) Classical and self-regulation 1 (government agency $B$ regulates firm $A$, which is also regulated by a trade group of firms on an contractual basis);

3) Classical and self-regulation 2 (government agency and trade association $B$ regulates firm A, which also self-regulates through intra-firm attempts (e.g. corporate social responsibility) to address these two types of external regulation); to

\footnotetext{
${ }^{9}$ George Manuel \& Michael Posluns, The Fourth World: An Indian Reality XI (foreword by Vine Deloria, Jr., 1974).

${ }^{10}$ See e.g. Colin Scott, Beyond Taxonomies for Private Sector Authority in Transnational Regulation, Presentation (March 2012), (slides on file with author); Peer Zumbansen, The Constitutional Itch, Presentation (March 2012), (notes on file with author).

${ }^{11}$ See also Colin Scott, Fabrizio Cafaggi \& Linda Senden, The Conceptual and Constitutional Challenge of Transnational Private Regulation 38(1) J. OF LAW AND Soc. 1, 11 (2011). ".... [I]t also becomes very clear from his [Cafaggi's] contribution that there is no question of a strict public-private divide in transnational governance, but that the relationship between the public and private spheres is intertwined and is being transformed in a variety of ways."

${ }^{12}$ See for example, Peer Zumbansen, Neither 'Public' nor 'Private', 'National' nor 'International': Transnational Corporate Governance from a Legal Pluralist Perspective 38(1) J. OF LAW AND Soc. 50, 56-57, 69-70 (2011) (on the collapsing and colliding of public-private, state-non-state and law-non-law distinctions).
} 
4) Transnational private regulation (government $B$ regulates firm $A, A$ regulates itself, and additionally $C$ (contracting party, whether another firm or the government, with potentially stronger remedies through contractual power than government regulation) and $\mathrm{D}$ (third parties like consumers, NGOs, and investors) perform regulation through social and market pressures (e.g. monitoring, shaming)). ${ }^{13}$

Implicit in the logic of this taxonomy, and most attempts to answer the question of public versus private, is the understanding that the government or the state is 'public', and firms, corporate actors, consumers, investors, and NGOs are some of the many shades that comprise the spectrum of 'private' (and thus potential private regulators). Of course, further complicating this state/non-state, or government/non-government, divide is the re-appropriation of what is 'public' in the sense of the commons or what is common to all. $^{14}$

Undoubtedly, just as migration is always already transnational, it is also always already private, too. Of course, this answer is only controversial insofar as readers might view migration as solely the concern of public law or the law and policy of states and their governments. If migration is not just about the relations of different state governments, whether internationally or inter-jurisdictionally (e.g. Canada-Ontario Immigration Agreement; Agreement for Canada-Alberta Cooperation on Immigration; Canada-OntarioToronto Memorandum of Understanding on Immigration and Settlement), then it clearly cannot be an affair that plays out solely on the public stage.

In a settled country like Canada, any number of migration and migrant work programs belie the notion that these are matters of and for public regulation only. And, as tedious as counting the angels dancing on the head of a needle (or pin) might be, the details of different migration schemes often betray their devils. Unless the government is also always the employer, migrant work programs imply the necessity of the private sector by their very name. In Canada, some examples include the Seasonal Agricultural Worker Program (SAWP), the Live-in Caregiver Program (LCP), and the Pilot Project for Occupations

\footnotetext{
${ }^{13}$ See above, Colin Scott, supra note 10.

${ }^{14}$ See generally Peter linebaugh, The Magna Carta Manifesto: Liberties and Commons for All (2008); Allan Greer, Commons and enclosure in the colonization of North America, 117(2) AM. HIST'L. REV. 365 (2012); MICHAEL HARDT \& Antonio NegRI, COMmONWEALTH (2009), but see criticism at Mark Driscoll, Looting the Theory Commons: Hardt and Negri's Commonwealth, 21(1) POSTMOd'N CUlt.; ElinoR OStrom, Governing the COMmONS: The EVolution of INSTIUTIONS FOR COlLECTIVE ACTION (1990); Karin Mickelson, Co-Opting Common Heritage: Reflections on the Need for South-North Scholarship, in HUMANIZING OUR GLOBAL ORDER: ESSAYS IN HONOUR OF IVAN HEAD 112-124 (Obiora Chinedu Okafor \& Obijiofor Aginam eds., 2003); See Colin Scott, Fabrizio Cafaggi \& Linda Senden, The Conceptual and Constitutional Challenge of Transnational Private Regulation 38(1) J. OF L. \& Soc. 1, 3-5 (2011); Lee Maracle, Toronto May Day Assembly 2011, YoUTUBE, available online at: www.youtube.com/watch?v=FNK3KDfMrRc (last accessed: 18 November 2012).
} 
Requiring Lower Levels of Formal Training (National Occupational Classification C \& D). In short, how Canadians (especially Ontarians) get their farmed food, care for their families, extract their resources, and are serviced in a post-industrial economy all rely on migrant workers who live in precarious situations to provide for themselves, their families, and their own nation-states in the form of remittances.

For instance, in comparison to Scott's fourth example in his TPR taxonomy, even a more managed migration program such as the SAWP is riddled with private actors as examples of $C$ and $D$ regulators beyond the classical $A$ to $B$ relationship. The SAWP entails memoranda of understanding (including standard form employment contracts) between states, and a host of relationships between consulates, trade associations of farmers, federal and provincial government immigration and human resources departments, individual employer farmers, travel agencies, individual migrant farm workers, trade unions, and community and advocacy groups. Following Scott's taxonomy, the firm, the federal government, the provincial government, the trade association, the foreign government, the worker, the community NGO, and the trade union are all present. The private structure of these migrant work programs are even further heightened under the lower skill pilot project (LSPP) of the Temporary Foreign Workers Program (TFWP) and the $L C P$, which comprise even less direct government or third-party regulation. ${ }^{15}$

Beyond the realm of so-called low skill migrant work, the private structures of migration and its regulation are further emphasized in Canada's formally permanent immigration system. ${ }^{16}$ As recently noted by Audrey Macklin:

[T] he vast majority of lawful immigrants gain entry not as workers, nor because they have a well-founded fear of persecution, but because of kinship. Historically, family-based migration formed an integral component of the nation-building

\footnotetext{
${ }^{15}$ Recent changes to the regulation of the TFWP by the Government of Canada place further faith in voluntary systems of private self-regulation. See for example, Judy Fudge \& Fiona MacPhail, The Temporary Foreign Worker Program in Canada: Low-Skilled Workers as an Extreme Form of Flexible Labor (31) COMP. LAB. L. \& POL. J. 101-139 (2009); Sarah Marsden, The New Precariousness: Temporary Migrants and the Law in Canada 27(2) CAN'N J. OF L. \& Soc. 209-229 (2012); Audrey Macklin, Foreign Domestic Worker: Surrogate Housewife or Mail Order Servant? 37 MCGILL L. J. 681-760 (1992).

${ }^{16}$ Under the SAWP, migrant farm workers are not able to apply for and transition to permanent resident status, which is permitted under the two-step immigration process of the LCP. Under the LSPP, there are very few paths to permanent status under provincial nominee programs (PNPs), the bulk of which favor workers in higher-skill occupation classes (O, A, \& B as opposed to C \& D). Further, migrant workers under the LSPP are barred for four years from working in Canada after they have already completed four years of work. Conversely, skilled immigrants entering under the points-based Federal Skilled Worker Program (FSWP) enjoy permanent resident status upon their arrival in Canada. Over the last decade or so, the Government of Canada has expanded the Temporary Foreign Worker Program (TFWP) at the request of employers while decreasing the number of entrants under the FSWP. The reduction of the latter program includes a government refusal to process a large number of skilled worker applicants under the euphemism of eliminating a long-standing backlog, due in part to the shift in resources to expeditiously process TFWP applications.
} 
enterprise of settler-societies like Canada and the United States. In most Western European states, family reunification and refugee admissions account for virtually all permanent admissions [...] In Canada, about 60 percent of permanent residents admitted in 2008 were designated by government statistics as members of the economic class, while approximately 27 per cent were members of the family class (the remaining 13 per cent were refugees and 'other'). However, this formal allocation masks the fact that statistics for the economic category include accompanying spouses and children of the principal applicant. [...] All this to say that close to 63 per cent of immigrants admitted to Canada in 2008 as permanent residents in the econcomic- or family-class stream actually gained entry because of their relationship to a person in Canada or to the person accepted for entry to Canada. The comparable figure for the United States is around 72 per cent. The conclusion that kinship overwhelms economic criteria as the avenue for entry holds true for both Canada and the United States, as well as for most other industrialized states. ${ }^{17}$

Between the dominance, even agency capture, ${ }^{18}$ of employers in migrant work schemes, and the determining role of families and kinship in the permanent immigration schemes, it should be safe to conclude that migration is as much private as it is public. The question remains whether the prescriptions or descriptions of transnational private regulation add to this reality and, if so, whether they allow migration to be something more than public (in the Westphalian sense) or private (in the sense of employer- or family-driven).

\section{Is Transnational Private Regulation of Migration Always Destined for Conflation with Market-Led or Market-Driven Regulation?}

In listening to some of the presentations and reviewing some of the relevant literature, I was struck by the directions and the targets of transnational private regulation. In Scott's talk, the cast of characters included state governments, firms, trade associations of firms, contracting governments and firms, and consumers, NGOs, investors, and other third parties. Presumably, the object of regulation is the firm and the potential regulators are any entity from 'command and control' states on down to supply chain-conscious window shoppers. However, in a different iteration by Fabrizio Cafaggi, TPR is said to describe the

\footnotetext{
${ }^{17}$ Audrey Macklin, Freeing Migration from the State: Michael Trebilcock on Migration Policy, 60 UNI. TORONTO. L. J. 315, 345-346 (2010, notes omitted).

${ }^{18}$ See e.g. Bill Curry, Boardroom confidential: What CEOs are asking of Jim Flaherty, THE GLOBE AND MAIL, Aug. 5, 2012, available online at: http://www.theglobeandmail.com/news/politics/boardroom-confidential-what-ceosare-asking-of-jim-flaherty/article4483479 (last accessed: 18 November 2012); Notes from Jim Flaherty's policy retreat, THE GLOBE AND MAIL, Aug. 15, 2012, available online at: http://www.theglobeandmail.com/news/politics/notes-from-jim-flahertys-policy-retreat/article4483497 (last accessed: 18 November 2012).
} 
distributive consequences and shift of regulatory power from the domestic to the global and from the public to the private. ${ }^{19}$ Still, in the case of transnational regulation of migration, or TPR of migration, who are the relevant actors - the regulators and the regulated?

If the state (B) is the metric, then presumably it will regulate the firm (A), as noted above and, where it falls short, will get by with a little help from its friends or enemies (C, D). However, in the case of migration, driven by the search for work and workers, settlers and settlement, and family expansion and reunification, it may very well be the case that it is the firm (A) that regulates the state (B), with or without the input of third parties (C, D). Or, to take just one, more realistic example from the SAWP, it may be that:

- $\quad$ one level of one state (B) seeks to facilitate migration

- $\quad$ at the request of some firms (A)

- $\quad$ or their association (A2)

- through contracts with another state (E), group of states (E2) and their consuls (E3)

- $\quad$ with direct regulation by another level of the receiving state (B2)

- $\quad$ and litigation, organizing, and advocacy by trade unions (C)

- $\quad$ and grassroots NGOs (D)

- $\quad$ with self-regulation by some firms (A),

- $\quad$ settlement work by some consumers (D2)

- $\quad$ and self-help by migrant farm workers themselves (F).

Since I am not from the school of legal analysis that operates in mathematical style thought experiments driven by individual letter representations, I will stop with the 'alphabet soup' here, except to say that this example does not even include the role of:

- $\quad$ families $(G)^{20}$

- $\quad$ households $(\mathrm{H})^{21}$

\footnotetext{
${ }^{19}$ Fabrizio Cafaggi, The New Foundations of Transnational Private Regulation, 38(1) J. OF L. \& Soc. 20-21 (2011).

${ }^{20}$ See e.g. Kerry Preibisch \& Evelyn Encalada Grez, The Other Side of el Otro Lado: Mexican Migrant Women and Labor Flexibility in Canadian Agriculture 35(2) SIGNS 289-316 (2010); Abigail Bakan \& Daiva Stasiulis eds., Not One of the Family: Foreign Domestic Workers in Canada (1997); Macklin, supra note 17.

${ }^{21}$ Janet Halley \& Kerry Rittich, Critical Directions in Comparative Family Law: Genealogies and Contemporary Studies of Family Law Exceptionalism (Introduction to the Special Issue on Comparative Family Law), 58 AMER. J. OF COMP. L. 753, 756, 758 (2010): seek to turn the traditional disciplinary focus of family law from a private, subordinated, feminine domain distinct from the public, masculine market, back towards the economic family and the household, as "an explicitly economic unit housing both human reproduction and material reproduction as well as a complex array of legal relationships," working from a definition of modern household used by systems theorists Immanuel Wallerstein and Joan Smith, i.e. "a human association bounded through social negotiation and aimed at securing human reproduction, including reproduction from day to day of its members as well as the
} 
- $\quad$ municipalities $(B 3)^{22}$

- $\quad$ regions $(B 4)^{23}$

- $\quad$ public international laws aimed directly at states, employers and workers $(I)^{24}$

- $\quad$ or private regulatory initiatives seeking indirect influence on these actors $(J) .{ }^{25}$

Beyond the single entity or associational form of TPR, it is not clear if this crowded constellation of actors corresponds even to the hybrid governance triangle. ${ }^{26}$ Instead, it would bear closer resemblance to a governance dodecagon.

As noted by Peer Zumbansen in his presentation, it is necessary to contend with the history of competing definitions of law in the seemingly inevitable turn to private transnational governance regimes. ${ }^{27}$ As seen in response to the first and second questions I have put to myself through the lens of transnational private regulation, the history of competing definitions of law is bound up in who or what counts as a source of authority in law. When discussing these sources of authority and the law, the issue of scale is integral to answering the questions of who gets regulated and who gets to regulate. ${ }^{28}$

At international law, initially, seemingly everyone had the right to travel, to trade, and to attempt to convert others to their own faith. ${ }^{29}$ To greater and lesser extents, two out of

production of new human beings. In liberal economic orders, it is an importance source of social security. In modern capitalism, it is a crucial site of consumption."

22 See e.g. SASkia SASSen, The Global City (2001); SASkia SAssen, The Mobility of Labor and CApital: A Study in INTERNATIONAL INVESTMENT AND LABOR FLOW (1988).

${ }^{23}$ See for example, Adelle Blackett \& Christian lévesque, Social Regionalism in the Global Economy (2011); Aprodicio laquian, Beyond Metropolis: The Planning and Governance of Asia's Mega-Urban Regions (2005).

${ }^{24}$ See infra note 31, regarding public international law measures.

${ }^{25}$ See e.g. Cafaggi, supra note 19 , at $48-49$.

${ }^{26}$ See Scott, Cafaggi, Senden, supra note 14, at 11.

${ }^{27}$ Zumbansen, supra note 10.

${ }^{28}$ See for example, Freeman, supra note 1; Schiller, supra note 2, at 58-61, discussing the importance of scalar perspectives on locality; Cristina Rodríguez, Building Capacity for the Transnational Regulation of Migration 110 COLUM. L. REV. SIDEBAR 1, 4 (2010), available online at: http://www.columbialawreview.org/building-capacity-forthe-transnational-regulation-of-migration (describing bilateralism mechanisms spanning federal cabinet level ministers, agency heads, border state governors, neighboring town mayors, and state and local officials seeking to attract new forms of investment).

${ }^{29}$ See also Georg CAVAlLar, The Rights of StRangers 2-3 (2002), defining international hospitality as the offering or affording of welcome and entertainment to strangers, visitors, or guests of members of different out-groups, cultures, and communities; contrasting Las Casas' view of benevolent indigenous hospitality with Vitoria's view of hospitality as "a right foreigners could enforce if denied" versus Kant's limited right of foreigners to visit in the absence of a special pact. 
three of these rights have been diluted over time. Conversely, the right to trade appears to be alive and kicking. ${ }^{30}$ But the right to travel, or international movement, or migration (permanent or otherwise), has not fared as well. ${ }^{31}$ Under international law, it can more accurately be described as the right to leave and a duty to avoid statelessness. But it does not comprise the right to enter or admission, or membership in a state. Further, those with the strongest argument for admission (or at least not being returned to death or torture) cannot be said to exercise their initial right to leave in the same way, since their migrations are forced. This story should also include, in the North American context at least, recognition of the long history of the problems of migrant work: from the unfree labor of 'free' slavery, to indentured servitude, and then the precarious status of farm, domestic and other migrant workers to this day.

The traditional, public, inter-state regulation of migration and migrant work emerges under three or four main regimes (human rights, labor, trade, and crime) through a long list of public international law instruments. ${ }^{32}$ There have been numerous criticisms of these conventions and declarations for their fragmentation, lack of ratification or lack of implementation, whether through the UN, ILO, WTO, the IOM, or individual states,

${ }^{30}$ See e.g. Antony Anghie, Imperialism, Sovereignty and the Making of International Law, ch. 4-5 (2005); Martti Koskenniemi, Empire and International Law: The Real Spanish Contribution 61(1) UNIV. TORONTO L. J. 1, 36 (2011), "[t]here is no doubt on which side imperialism has gained its greatest victories: since decolonization, Western domination of the 'people without history' has returned to its classical mainstay, informal empire, the creation of wealth and influence and the distribution of material and spiritual resources through the exercise of private power. Today's ius gentium continues to be divided into the law of treaties, on the one side, and the law of contract, on the other. There is no doubt on which side the most significant aspect of dominium - that is, the power of human beings over other human beings - is exercised."

${ }^{31}$ See e.g. Tony Anghie \& Wayne McCormack, The Rights of Aliens: Legal Regimes and Historical Perspectives, in

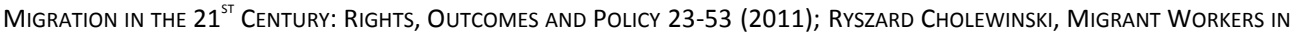
International human Rights LAW: Their Protection in Countries of EMployment (1997); Ryszard Cholewinski, The human and labor rights of migrants: vision of equality, 22(2) Georgetoen Imm. L. J. 177 (2008); Joel Trachtman, The International Law of Economic Migration: Toward the Fourth Freedom (2009); Chantal Thomas, Convergences and Divergences in International Legal Norms on Migrant Labor, 32 COMP. LAB. \& POL'Y J. 405 (2011).

${ }^{32}$ See for example, id. Summarizing from these authors, a brief list would include: diplomatic protection \& state responsibility doctrine, the Vienna Convention on Consular Relations, ILO Conventions 97 and 143, the International Covenant on Civil and Political Rights (ICCPR), International Covenant on Economic, Social and Cultural Rights (ICESCR), the Convention on the Elimination of All Forms of Discrimination Against Women (CEDAW), the International Convention on the Elimination of All Forms of Racial Discrimination (CERD), the Convention on the Rights of the Child (CRC), the Convention Regarding the Status of Refugees, the Convention against Torture (CAT), the Convention on the Rights of All Migrant Workers and Members of their Families (UNCMW), the (Palermo) Protocols to Prevent, Suppress and Punish Trafficking in Persons, Especially Women and Children and Against the Smuggling of Migrants by Land, Sea and Air (supplements to the UN Convention against Transnational Organized Crime), the WTO, General Agreement on Trade in Services, Mode 4 (liberalizing the temporary movement of people providing services and erstwhile promotion of a GATS visa). There have also been calls for a World Migration Organization (akin to the WTO and beyond the ILO, what might have come to pass as a post WWI, Fourth Bretton Woods Institution); See Trachtman, id. at Chapter 9; BIMAL GHOSH, MANAGING Migration: Time for a NeW INTERNATIONAL Regime? (2000). 
especially for failing irregular migrants with precarious status and so-called low-skill or lowwage migrant workers. ${ }^{33}$ Some of these instruments only deal with protection after entry, which is the crux of the problem at international law given the 'beefing up' of borders and the emphasis on security. Similarly, while some regimes like the WTO/GATS work with the expectation of a 'falling away' or liberalization of borders, others like the Palermo protocols potentially criminalize every act of border crossing. ${ }^{34}$

These instruments and their failures all relate to those migrants of most concern to my research, so-called low-skill migrants in precarious status, whether because their status is temporary or because it is irregular/non-status. These failures mirror those of national, domestic policies, both in the consistent failure to abide by these conventions and declarations but also in these states' failure to acknowledge long-term needs for and structural drivers of so-called low-skill, low-wage work. ${ }^{35}$

In the shadow, as supplements, as complements, and in bypass of these public international law regulations, different discussions of the transnational regulation of migration, migrant work/work, or of labor itself seek to address some of these issues, though most do not explicitly adopt the label of 'private'. ${ }^{36}$ Strikingly, these interventions

\footnotetext{
${ }^{33}$ See for example Ryszard Cholewinski, PAUl de Guchteneire \& Antoine PÉcoud eds., Migration and Human Rights: THE UnIted Nations of Convention of Migrant Workers' Rights (2009); Judy Fudge, The Precarious Migrant Status and Precarious Employment: The Paradox of International Rights for Migrant Workers, No. 11-15 METROPOLIS WORKING PAPER SERIES (2011).

${ }^{34}$ See Elspeth Guild, Security and Migration in the $21^{\text {ST }}$ Century, ch. 8 (2009). In this vein, even as it expands and expedites the TFWP, the Government of Canada has also instituted specific, special protections and restrictions for potentially trafficked sex workers in the adult entertainment industry; see Human Resources and Skills Development Canada, Notice to Employers: Sex Trade-related Businesses, available online at: http://www.hrsdc.gc.ca/eng/workplaceskills/foreign_workers/communications/trade.shtml (last accessed: 18 November 2012).

${ }^{35}$ In Canada, these 'low skill' workers would fall under the national occupational classification (NOC) C \& D as those with only secondary or lesser education. Recent changes have been announced to expand permanent immigration under the Federal Skilled Worker Program to include skilled trades under the points-system approach. More generally on this point of 'the path not taken', see Castles. See also Mark Thompson, Introduction, Symposium on Migrant Workers in Canada, Germany, New Zealand, the UK, \& the US, 31(1) CoMP. LAB. L. \& POL. J. 3 (2009).

${ }^{36}$ See Tim Bartley, Institutional Emergence in an Era of Globalization: The Rise of Transnational Private Regulation of Labor and Environmental Conditions, 113(2) AMER. J. OF SOCIOLOGY 297-351 (2007); Kevin Kolben, Transnational Labor Regulation and the Limits of Governance, 12(2) THEO'L INQ. IN L. 1-35 (2011); Cristina Rodríguez, Building Capacity for the Transnational Regulation of Migration, 110 COLUM. L. REV. SIDEBAR 1 (2010), available online at: http://www.columbialawreview.org/building-capacity-for-the-transnational-regulation-of-migration/; Jennifer Gordon, Transnational Labor Citizenship, 80(3) SOUTH. CAL. L. REV. 503 (2007), advocating extending global labor solidarity through transnational unions for migrant workers; Jennifer Gordon, Towards Transnational Labor Citizenship: Restructuring Labor Migration to Reinforce Workers Rights, THE WARREN INSTITUTE POLICY PAPER (2009), available online at: http://papers.ssrn.com/sol3/papers.cfm?abstract id=1348064 (last accessed: 18 November 2012); David Doorey, In Defense of Transnational Domestic Labor Law, 42 VAND. J. OF TRN'L L. 953-1009 (2010); Harry W. Arthurs, Making Bricks Without Straw: The Creation of a Transnational Labor Regime (June 30, 2012)
} 
and descriptions tend to focus more on issues of global labor solidarity, ${ }^{37}$ regulation as compromised settlements of conflict in the political constructions of markets, ${ }^{38}$ and mechanisms of bilateralism that build cross-border accountability through strong ties with representative public institutions. ${ }^{39}$

If the targets of transnational regulation are states as much as firms, and the regulators are workers as much as states, what are the implications from emphasizing some of the regulated and the regulators more than others? Does the emphasis on 'private' as nonstate, in order to encompass NGO and trade union, as much as corporate, activity, occlude the public interest or social justice orientation of many of the efforts at transnational, multi-scalar regulation of migration and migrant work?

These questions may only be matters of adjectives. Explicitly, TPR is not focused on advocating for or describing private actors in the sense of regulation by markets alone or solely business-led regulation. ${ }^{40}$ And certainly, there is optimism that the expanded scope provided by TPR would be beneficial in and of itself. ${ }^{41}$ Or, as put by Bartley, TPR is preferable to the alternatives of ineffective or incomplete inter-governmental regulation, the pure symbolism of post-crisis corporate regulation, or doing nothing at all. ${ }^{42}$

However, in his case study of certification standards for forest products and the apparel industry, Bartley reports that TPR's success turns in part on the political and economic

Osgoode CLPE Research Paper No. 28/2012, available online at: http://ssrn.com/abstract=2139204; Cynthia Estlund, Enforcement of private transnational labor regulation: a new frontier in the anti-sweatshop movement? in Fabrizio Cafaggi, ed., ENFORCEMENT OF TRANSNATIONAL REGULATION: Ensuring Compliance in a Global World, 237-262 (2012).

${ }^{37}$ See Gordon, id., cf. Leah Vosko, supra note 2, at note 91, noting three limitations of transnational labor citizenship, namely its 'closed shop' approach, differential gendered impact, and only interim approach. See also Hog workers approve contract that aids foreign workers: deal with Maple Leaf Foods helps fast-track immigration status, CBC.CA, Jan. 5, 2010, available online at: http://www.cbc.ca/news/canada/manitoba/story/2010/01/05/mb-foreign-workers-contract-maple-leafmanitoba.html (last accessed: 18 November 2012). But $c f$. Fudge re BCLRB/HRT SELI case and difficulty obtaining equal employment rights, even for temporary workers who are unionized (with backdrop that most are not unionized, due to concentration in agriculture, domestic work, and hospitality \& food service).

${ }^{38}$ See Bartley, supra note 36, at 300-312; Kolben, supra note 36, at 410, 433 and following.

${ }^{39}$ See Rodriguez, supra note 36 , generally and at 11.

${ }^{40}$ See Scott, Cafaggi, Senden, supra note 14, preference for term 'private' rather than 'nonstate' "in the sense that key actors in such regimes include both civil society or non-governmental organizations (NGOs) and firms (both individually and in associations).

${ }^{41}$ See Scott, Cafaggi, Senden, supra note 40, at 18-19; Rodriguez, supra note 36.

${ }^{42}$ Bartley, supra note 36 , at 305, 328. 
context of the target industries as much as domestic and geopolitical considerations. ${ }^{43}$ More specifically, what was politically possible for forest products certification was not the case for the sweatshops of the apparel industry, where both firms and the government of the day preferred neoliberal, private standards systems that would address media and consumer uproars without drastically altering the means of production. ${ }^{44}$ In a different context, discussing the combination of transnationalism with critical migration studies, Nina Glick Schiller emphasizes the need to look beyond the nation-state unit and migrants as mere disruptions to that unit, focusing instead on scalar perspectives on locality, transnational fields of power, and multiple entry points and pathways of local and transnational incorporation. ${ }^{45}$ In advocating for a global power perspective that is alive to the "global fragility of contemporary capitalism," Schiller includes the identification of "migrants as legitimate and necessary actors[s] of movements for progressive social transformation."

All of these questions ultimately go back to the main concerns of my doctoral research on the relationship between racialized migrants and Indigenous peoples in Canada, and the erasure of Indigenous laws and legal traditions as sources of authority within that relationship. $^{47}$ If migration is always transnational (and not just inter-state international) and migration is always private (in the sense of non-state, but also as social and something held in common as much as colonialism), then it is important to continue to pursue regulation (transnational, private, or otherwise) that provokes and is provoked by the histories and structures of regulatory conflicts. For migrants and Indigenous peoples, among many others, these histories and structures point to the need to move beyond state-centric and market-led initiatives. ${ }^{48}$ In this vein, a brief answer to my final rhetorical question concludes this article with two vignettes about the laws of eating.

\footnotetext{
${ }^{43}$ Id. at 331-333.

${ }^{44}$ Id. at 335-337.

${ }^{45}$ Schiller, supra note 2 , at 42 .

${ }^{46}$ Schiller, supra note 2 , at 65 .

${ }^{47}$ For related work, see Amar Bhatia, The South of the North: Building on Critical Approaches to International Law with Lessons from the Fourth World, 14 OREGON REV. OF INT'L L. 131 (2012) TWAIL Symposium.

${ }^{48}$ See e.g., note 24 above re commons. See for example, Peter Nyers, No One Is Illegal Between City and Nation, 4(2) STUDIES IN SOC. JUST. 127 (2010) .
} 


\section{Can Transnational Private Regulation of Migration Be Part of the Solution - In a Settled Country Like Canada, Will It Help Everyone to Eat?}

Published in 1923, Robert Hale wrote in an article called 'Coercion \& Distribution in a Supposedly Non-Coercive State':

He must eat. While there is no law against eating in the abstract, there is a law which forbids him to eat any of the food which actually exists in the community and that law is the law of property. [...] It is the law that coerces him into wagework under penalty of starvation - unless he can produce food. Can he? Here again there is not law to prevent the production of food in the abstract; but in every settled country there is a law which forbids him to cultivate any particular piece of ground unless he happens to be an owner. This again is the law of property. ${ }^{49}$

Hale's compact description of the problems of work and migration (internal, external, rural, urban, etc.) and their mutual constitution with the laws of property relate intimately to the mutual constitution of these very laws of property with settler sovereignty in Canada and elsewhere. The assertion of Crown sovereignty, the arrogation of title, the dispossession of Indigenous lands and wealth, the re-concentration of that wealth, and the coercion of property laws in service of owners all structure social, political and economic life in the state of Canada as well as for those seeking to enter, work, and live in Canada. The production of food, the pursuit of family life, and standing as legal and political subjects are particularly stark for Indigenous peoples and racialized migrants in Canada, especially where people fall out of status under the governing regimes of both populations. $^{50}$

As I began this article, in part by acknowledging the traditional territory where the conference took place, it is equally important to acknowledge that Indigenous laws and legal traditions remain vibrant in Canada. ${ }^{51}$ Going further, and taking transnational private regulation as an approach that should be concerned with markets without being led by them, it is also important to know that Indigenous laws have much to say about the regulation of migration. Despite their importance, these laws and traditions do not enjoy equal recognition by the state or its courts, especially in the context of migration and

\footnotetext{
${ }^{49}$ Robert Hale, Coercion and Distribution in a Supposedly Non-Coercive State, 38 POL. SCI. QT'LY 470, 472-473 (1923).

${ }^{50}$ See Constitution Act, 1867, 30 \& 31 Victoria, c. 3 (U.K.) [British North America Act]; Immigration and Refugee Protection Act, S.C. 2001, c 27; Indian Act, RSC 1985, c I-5.

${ }^{51}$ See e.g. John Borrows, Recovering CANAdA: The Resurgence of Indigenous LaW (2002); John Borrows, Canada's INDIGENOUS CONSTITUTION (2010); Bhatia, supra note 47.
} 
notwithstanding the factor of delegated, constrained kinship determination. ${ }^{52}$ Writer, poet and Sto:lo traditional teacher Lee Maracle recently spoke about Host Law as a necessary counter law in the context of political struggle against the privilege of the dominant settler society. Maracle linked the need for mutual recognition of Indigenous sovereignty along with the principle that 'no one is illegal' (whether a 'bastard child' or 'illegal alien'). Of most importance to the above discussion on the transnational regulation of migration, Maracle also said that Host Law is very simple and can be boiled down to three things:

- $\quad$ Everybody eats. ${ }^{53}$

- $\quad$ Every woman is entitled to a house.

- $\quad$ Everybody has access to the unlimited wealth of the land. But with the caveat: Take only what you need. ${ }^{54}$

The question of whether transnational private regulation helps or hinders the transformation of these principles into practices - that no one is illegal ${ }^{55}$, that everybody eats - remains an open one.

\footnotetext{
52 This point is developed at length in my doctoral work. On the constrained delegation of membership criteria, see (among others): PAMELA PALMATER, BEYOND BLOOD: RETHINKING INDIGENOUS IDENTITY (2011).

${ }^{53}$ See e.g. Leanne Simpson, Looking after Gdoo-naaganinaa: Precolonial Nishnaabeg Diplomatic and Treaty Relationships, 23 WICAZO SA REV. 29, 37 (2008), discussing the 'Common Dish' relationship between Nishnaabeg people and the Haudenosaunee Confederacy.

${ }^{54}$ Maracle, supra note 14 , at the 2:39 minute mark and following.

${ }^{55}$ Nyers, supra note 48.
} 